\title{
Psikolojik Sermayenin Bireysel Performans Üzerindeki Etkisinde Birey-Örgüt Uyumunun Aracılık Rolü: Vakıf Üniversitelerindeki Öğretim Üyelerine Yönelik Bir Araştırma ${ }^{1}$ \\ (Mediating Role of Person-Organization Fit in The Effect of Psychological Capital on Individual Performance: A Research on The Academicians in Foundation Universities)
}

\section{Osman Seray ÖZKAN ${ }^{\text {ID }}$ Tolga OMAY}

a Türk Hava Kurumu Üniversitesi, Sosyal Bilimler Enstitüsü, Ankara, Türkiye. osmanserayozkan@gmail.com

b Atılım Üniversitesi, İşletme Fakültesi, İktisat Bölümü, Ankara Türkiye. tolga.omay@atilim.edu.tr

\begin{tabular}{|c|c|}
\hline MAKALE BİLGİSI & ÖZET \\
\hline $\begin{array}{l}\text { Anahtar Kelimeler: } \\
\text { Psikolojik sermaye }\end{array}$ & $\begin{array}{l}\text { Amaç - Bu araştırma, psikolojik sermayenin bireysel performans üzerindeki etkisini ve birey- } \\
\text { örgüt uyumunun bu iki değişken arasındaki aracılık rolünü tespit etmek amacıyla } \\
\text { gerçekleştirilmiştir. }\end{array}$ \\
\hline $\begin{array}{l}\text { Birey-örgüt uyumu ve yapısal } \\
\text { eşitlik modellemesi. }\end{array}$ & $\begin{array}{l}\text { Yöntem - Araştırmanın örneklemini, Türkiye'deki vakıf üniversitelerinde görev yapmakta olan } \\
433 \text { akademik personel oluşturmuştur. Anket formu, mail yoluyla ve online anket sistemi } \\
\text { aracılığıyla gönderilmiştir. Elde edilen veriler üzerinde frekans analizi, güvenirlik analizi, } \\
\text { korelasyon analizi, açımlayıcı ve doğrulayıcı faktör analizi ile yapısal eşitlik modellemesi } \\
\text { kullanılmıştır. }\end{array}$ \\
\hline $\begin{array}{l}\text { Revizyon Tarihi } 3 \text { Nisan } 2019 \\
\text { Kabul Tarihi } 4 \text { Mayıs } 2019\end{array}$ & $\begin{array}{l}\text { Bulgular - Araştırma sonuçları, psikolojik sermayenin birey-örgüt uyumu ve bireysel } \\
\text { performans ile pozitif yönde ilişkisi olduğunu göstermiştir. Ancak araştırmanın ana hipotezi } \\
\text { olarak belirlenen, psikolojik sermaye ile bireysel performans arasındaki ilişkide birey-örgüt } \\
\text { uyumunun aracılık rolü desteklenmemiştir. }\end{array}$ \\
\hline $\begin{array}{l}\text { Makale Kategorisi: } \\
\text { Araştırma Makalesi }\end{array}$ & $\begin{array}{l}\text { Tartışma - Bu sonuçlara göre; psikolojik sermayesi yüksek olan birey, pozitif çıktıların elde } \\
\text { edilmesi yönünde eğilimli hale gelerek çalışma isteğini artırmakta ve bu da süreç içerisinde } \\
\text { daha yüksek performans sergilemesine neden olmaktadır. Ayrıca psikolojik sermayesi yüksek } \\
\text { olan bireyin çalıştığı örgütle özdeşleşmesi ve yaptığı iş ile olan uyumunun artması neticesinde, } \\
\text { örgütün genel başarı düzeyi ve verimliliği artmaktadır. Örgütün amaçları ve değerleri ile } \\
\text { özdeşleşen bireyin performansının artması neticesinde, kişisel ve örgütsel hedeflere ulaşma } \\
\text { düzeyi de yükselmektedir. Bu araştırmanın, vakıf üniversitelerindeki akademisyenler hakkında } \\
\text { yapılacak çalışmalara katkı sağlayacağı ve psikolojik sermaye, bireysel performans ile birey- } \\
\text { örgüt uyumu düzeyleri hakkında araştırmacılara ve uygulayıcılara fikir vereceği } \\
\text { değerlendirilmektedir. }\end{array}$ \\
\hline
\end{tabular}

\begin{tabular}{l}
\hline ARTICLE INFO \\
\hline Keywords: \\
Psychological capital \\
Individual performance \\
Person-organization fit and \\
structural equation modeling
\end{tabular}

ABSTRACT

Purpose - This research was carried out to determine the impact of psychological capital on individual performance and the mediating role of person-organization fit between these two variables.

Design/methodology/approach - The sample of the study is 433 academic staff who work in foundation universities in Turkey. The questionnaire was sent to the academic staff at the foundation universities via e-mail and through the online survey system. Frequency analysis, reliability analysis, correlation analysis, explanatory and confirmatory factor analysis and

Received 2 January 2019

Revised 3 April 2019 structural equation modeling were used on the obtained data.

Accepted 4 May 2019

Findings - Research results showed that psychological capital has a positive relationship with person-organization fit and individual performance. However, the mediating role of personorganization fit in the relationship between psychological capital and individual performance, which was determined as the main hypothesis of the research, was not supported.

Article Classification:

Discussion - According to these results, the individual with high psychological capital will increase his / her willingness to work by getting positive outputs and this will lead to show higher performance in the process. In addition, the general success level and productivity of the organization will increase as a result of the fit of the individual with high psychological capital to the organization and the work. As a result of increased performance of the individual fit with

${ }^{1}$ Bu makale, Prof. Dr. Tolga OMAY'ın danışmanlığında hazırlanan Osman Seray ÖZKAN'ın doktora tezinden uyarlanmıştır. 
the aims and values of the organization, the obtained level of the personal and organizational targets will also get high. It is evaluated that the research will contribute to the studies to be done about the academicians in foundation universities and to give an idea to the researchers and practitioners about the levels of psychological capital, individual performance and personorganization fit.

\section{Giriş}

Politik, kültürel, bilimsel ve sosyo-ekonomik faktörler, insana verilen önemi her geçen gün artırmaktadır. Sürdürülebilir rekabet avantajı sağlamada, çalışanların önemli bir rolünün olduğu örgütler tarafından anlaşılmaktadır. Ekonomik, beşeri ve sosyal sermaye türlerinden farklı olarak "kişinin kim olduğuyla" ve "olumlu gelişimi açısından ne olabileceğiyle" ilişkili (Çetin vd., 2013: 99) olan psikolojik sermaye kavramı günden güne önem kazanmaya başlamıştır. Bireyin pozitif gelişme durumunu ifade eden psikolojik sermaye, bireysel performansı ve birey-örgüt uyumunu artırma aracı olan motivasyon unsurlarından birisi olarak değerlendirilmektedir. Bunun yanında, çalışanların performansı ve birey-örgüt uyumları da örgütler açısından önemli faktörlerdir. Bireyin değerleri ile bireyin içinde yer aldığı örgütün değerlerinin uyum içinde olması şeklinde tanımlanan birey-örgüt uyumu (Saraç ve Meydan, 2013: 210); örgütsel bağl1lı̆̆ı, örgütsel aidiyeti, iş tatminini ve iş performansını olumlu yönde etkilemektedir.

Küreselleşen dünya ekonomisi ile birlikte ortaya çıan rekabet şartlarında, örgütlerin varlıklarını sürdürmelerine ve başarılarını devam ettirmelerine katkı sağlayan psikolojik sermaye, bireysel performans ve birey-örgüt uyumunun farklı değişkenler ile değişik sektörlerde yapılan araştırmalarda pozitif iş çıtılarına, tutumlarına ve davranışlarına yol açtığı tespit edilmiştir.

Yapılan bu tespit doğrultusunda literatürde bu değişkenlerin, psikolojik sermaye ile bireysel performans ve birey-örgüt uyumu ile bireysel performans şeklinde incelendiği gözlenmiştir. Ancak yerli ve yabancı araştırmalarda, psikolojik sermaye ile birey-örgüt uyumu ilişkisi olan veya psikolojik sermaye ve bireysel performans arasındaki ilişkide birey-örgüt uyumunun aracılık rolü bulunan herhangi bir çalışmaya rastlanılmamıştır. Bu doğrultuda araştırma, literatürdeki bu boşluğu doldurmasının yanı sıra konuyla ilgili çalışmalara örnek teşkil etmesi bakımından da önem arz etmektedir. Ayrıca bu ilişkinin akademik personel üzerinde uygulanıyor olması da, bu alanda yapılacak çalışmalarda karşılaştırmaların yapılmasına olanak sağlayacaktır. $\mathrm{Bu}$ açıdan değerlendirildiğinde araştırma, psikoloji ve örgütsel davranış alanında yer alan diğer çalışmalardan farklı olarak nitelendirilebilir. Bu bilgilerden hareket edilerek bu araştırmanın temel sorusu; "psikolojik sermaye, birey-örgüt uyumu aracılı̆̆ıyla mı bireysel performansı etkilemektedir?" olarak belirlenmiştir.

Araştırmada öncelikle psikolojik sermayenin, bireysel performansın ve birey-örgüt uyumunun kavramsal çerçevesine yer verilmekte ve değişkenlerin literatürde yer alan ilişkileri incelenerek araştırma hipotezleri oluşturulmaktadır. Araştırmanın uygulama bölümünde; araştırmanın modeli, evreni ile örneklemi ortaya konulmakta, veri toplama araçları ve verilerin analizi konularına açıklık getirilerek değişkenlerin dahil edildiği yapısal model test edilmektedir. Araştırmanın son bölümünde ise ortaya çıkan sonuçlar tartışılmaktadır.

\section{Kuramsal Çerçeve}

\subsection{Psikolojik Sermaye}

Tarihsel açıdan bakıldığında; önceleri insanların bilinçaltında kalan düşüncelerini ve bilinmeyen yönlerini araştırıp hastalık, başarısızlık, çaresizlik ve tükenmişlik gibi olumsuz durumları inceleyen psikoloji bilimi, daha sonraları pozitif psikoloji hareketi ile birlikte bireylerin modern yaşamda hayat kalitesinin nasıl yükselebileceği ve nasıl daha mutlu olabilecekleri üzerinde durmaya başlamıştır (Caprara ve Cervone, 2003: 61). Seligman, Diener, Peterson ve Snyder, psikoloji biliminin insanların sadece zayıf ve olumsuz davranışlarına odaklanmasının yanı sıra güçlü ve olumlu yanlarını da anlayıp geliştirerek daha normal, daha iyi ve daha başarılı bireyler olmayı öğrenebilmek için kullanılması gerektiğini ileri sürerek ilk kez 1990’lı yıllarda "pozitif psikoloji" kavramını ortaya atmışlardır (Linley vd., 2006: 3).

Pozitif psikoloji, normal sağlıklı bireyleri inceleyerek, bu bireylerde neyin doğru gittiğini ve neyin geliştirilebilir olduğunu bulmaya çalışmaktadır. Bireyin, kendi potansiyelinin farkına varmasının yanında 
olumlu ve güçlü yönlerine odaklanarak daha üretken ve daha mutlu olmasını sağlamaktadır (Kümbül Güler, 2015: 140).

Pozitif psikolojinin örgütsel yaşama yansıması olarak ortaya çıkan pozitif örgütsel davranış kavramı ise; örgüt ortamında çalışanların mutlu ve huzurlu olmalarının performansı ve verimliliği artıracağı düşüncesiyle örgüt içerisinde olumlu davranışlar geliştirmeye odaklanmaktadır (Erkuş ve Fındıklı, 2013: 303).

Luthans ve arkadaşları, pozitif psikoloji ve pozitif örgütsel davranış kavramlarından yola çıarak ekonomik sermaye, sosyal sermaye ve insan sermayesini analiz etmişler ve bireylerin pozitif güçlerine odaklanan psikolojik sermaye kavramını ortaya koymuşlardır (Zhao ve Hou, 2009: 35).

Pozitif örgütsel davranış araştırmaları neticesinde ortaya çıkan bir kavram (Luthans vd., 2007) olan psikolojik sermaye; çalışanların problemli ve yanlış yönlerine odaklanmak yerine, çalışanlar için neyin doğru ve iyi olduğuna odaklanmaktadır. Örgüt üyelerinin sergiledikleri davranışlar ile örgüt çıtıları arasında ilişki kurmaktadır (Luthans, 2002: 696-697).

Psikolojik sermaye; öz yeterlilik, umut, iyimserlik ve dayanıklılık boyutlarının birleşiminden oluşan bir kavramdır (Erkmen ve Esen, 2013: 24). Psikolojik sermayenin öz yeterlilik boyutu, hedeflere ulaşabilmek için bireyin tüm potansiyelini ve yeteneklerini ortaya koyma konusunda kendine duyduğu güveni; umut boyutu, amaçlara ulaşmada istenç sahibi olmayı ve farklı yollar düşünebilmeyi (Luthans ve Youssef, 2004: 153); dayanıklılık boyutu, başarısızlık veya sorumluluğun artması gibi beklenmedik durumlarda kişinin kendini toparlayabilme ve yenileyebilme kapasitesini (Keleş, 2011: 348); iyimserlik boyutu ise kişinin kendine güven duygusuyla birlikte şimdi ve gelecekte başarılı olmaya yönelik olumlu düşüncesini ifade etmektedir (Çetin vd., 2013: 99).

Pozitif örgütsel davranış akımı doğrultusunda ortaya çıkan ve çalışanların güçlü yönlerine vurgu yapan psikolojik sermaye, bireysel performansı artırma aracı olan motivasyon unsurlarından birisi olarak değerlendirilmektedir.

\subsection{Bireysel Performans}

Örgütlerin amaçlarını gerçekleştirebilmesi ve faaliyetlerini devam ettirebilmesi için toplumun ihtiyaç duyduğu mal ve hizmetleri üretmesi gerekmektedir. Örgütler, amaçlarını gerçekleştirebilmek için fiziksel üretim unsurlarının yanında, kaliteli insan gücüne de ihtiyaç duymaktadır. İş görenlerin iş görme yeteneklerinin nasıl olduğunun belirlenememesi, örgütlerde karşılaşılan en önemli sorunlardan birisidir. Bu sorun, günümüz örgütlerinde performans kavramının önemli bir yeri olduğunun anlaşılmasına neden olmuştur.

Performans; bir amaca yönelik planlanmış bir faaliyet sonucunda ortaya çıkan, sonucu nicel ya da nitel olarak belirleyebilen, mutlak veya göreli olarak açıklayabilen ve ölçütler sonucunda değerlendirilebilen bir kavramdır (Akal, 1996: 1).

Örgütlerde yürütülen performans çalışmalarının temel unsuru insanlardır. Örgütlerin en değerli varlıklarının insan olduğu değerlendirildiğinde, onlardan en yüksek faydayı elde etme düşüncesi bireysel performansı ilgi odağı haline getirmektedir.

Bireysel performans, iş görenlerin örgütün hedeflerine ulaşması adına örgütün onlardan beklentilerini yerine getirmelerine yönelik en üst seviyede çaba göstermeleri ve ortaya konulan bu çabadan elde edilen çıtıların örgütün hedefleri ile paralellik göstermesidir (Katerberg, 1983: 250).

İstenilen performans düzeyinin sağlanmasında en önemli iki etmenin, bireyin yeteneği ve motivasyonu olduğu ortaya konulmuştur. Yetenekleri aynı olan iki kişinin motivasyon seviyelerine göre farklı performans gösterdikleri kanıtlanmıştır (Young, 1936; akt.; Larousse, 1969: X/37). Bireysel performans; kişilik, değerler, tutumlar, bireyin yetenekleri ve motivasyonu ile geliştirilebilmektedir (Marchant, 1999: 63).

Bununla birlikte, bireylerin karakteristik özelliklerini performanstaki değişimin ana nedeni olarak gören, aynı zamanda çalışma yaşamını ve örgütsel psikolojiyi de içine alan bir kavramdır (Sonnentang ve Frese, 2002: 3-4). Örgütsel davranışın sonuç değişkenlerinden birisi olan bireysel performansın, birey-örgüt uyumu ile de ilişkisi bulunmaktadır. 


\subsection{Birey-Örgüt Uyumu}

Kavramsal olarak birey-örgüt uyumu; bir tarafın (birey veya örgüt), karşı tarafın ihtiyaçlarını karşıladığı veya benzer karakteristik özellikler paylaştıkları (Kristof, 1996; 4); ya da bireyin özniteliklerinin, işin nitelikleri ile uyumlu olması şeklinde ifade edilmektedir (O'Reilly III vd., 1991: 488).

Birey-örgüt uyumu, işverenin nitelikli iş gücü beklentisi ile çalışanın örgütten beklentilerinin dengede olması halinde ortaya çıkmakta ve çalışanın işe yönelik tutum ve davranışlarını etkilemektedir (Kristof, 1996; akt.: Turunç ve Çelik, 2012: 60).

Birey-örgüt uyumunun kapsamı konusunda literatürde farklı görüşler de bulunmaktadır. Meglino vd., (1989; 427) tarafından değer uyumu, Vancouver ve Schmitt (1991: 334) tarafından hedef uyumu, Bretz vd., (1988: 7) tarafından istekler-yetenekler uyumu olarak ifade edilmiştir. Bu görüşlere göre, birey-örgüt uyumunu sağlamak için dört yöntem bulunmaktadır. Birinci yöntemde, çalışanın ve örgütün temel özelliklerindeki benzerlikler üzerine odaklanılmaktadır (Kristof, 1996: 5). İkinci yöntemde, örgüt liderleri ile astların hedeflerinin uyumu sağlanmaya çalışılmaktadır (Vancouver vd., 1994: 668). Üçüncü yöntemde, kişisel tercih ya da ihtiyaçlar örgüt yapısı ve sistemi ile uyumlu hale getirilmektedir (Cable ve Judge, 1994: 326). Dördüncü yöntemde ise şahısların kişiliği ile örgütün kişiliği olarak tanımlanan örgüt iklimi arasında uyuma odaklanılmaktadır (Kristof, 1996: 6).

Birey-örgüt uyumu, çalışanların değerlerinin örgütsel üyeliğin bir fonksiyonu olarak organizasyonel normlara ne ölçüde uyacağını ve ne ölçüde değişeceğini tahmin etme kabiliyetini artırmaktadır (Chatman, 1989: 342). Birey-örgüt uyumu düşük olan işletmeler ile uyumun yüksek olduğu işletmeler rekabet durumunda kaldıklarında, birey-örgüt uyumu yüksek olan işletmelerdeki kilit yeteneklere sahip çalışanların örgütten çekilip alınmaları daha zor olmaktadır (Cheng, 2014: 126). Çünkü bu uyum örgütün çalışanları için bir bağlllık ve isteklilik anlamına gelmekte olup, örgütün verimliliğini artırmaktadır (Farooquia ve Nagendra, 2014).

Bireysel ve örgütsel değerler arasında sağlanan yüksek düzeydeki uyumun her iki taraf için de pozitif sonuçlara neden olduğu yapılan araştırmalar neticesinde (Bright, 2007; Chatman, 1989; Kristof, 1996; Kılıç, 2010; O'Reilly III ve Chatman, 1986; Yahyagil, 2005) tespit edilmiştir. Bu çalışmaların sonuçları, bireylerin kendi değerleri ile özdeşleşen organizasyonlarda çalışmayı tercih ettiklerini göstermektedir.

Ekonomik ve teknolojik değişimlerin yaşandığı bilgi çağında ve yoğun rekabet ortamında örgütler, iş görenlerinin örgüte ve yaptıkları işe olan uyumlarını maksimum seviyeye çıkarmalıdır. Birey-örgüt uyumu; hem birey hem de örgüt tarafından sağlanan bilinçli bir uyum ve sürdürülebilir bir rekabet avantajı elde etmek, yenilikçi ürünler meydana getirmek, müşteri beklentilerine hızlı cevap verebilmek, örgütlerde esneklik kabiliyetini artırmak, kaynakların etkin ve verimli kullanılmasını sağlamak için gereklidir.

\subsection{Psikolojik Sermaye, Bireysel Performans ve Birey-Örgüt Uyumu İlişkisi}

Psikolojik sermaye ile performans arasındaki ilişkinin incelendiği yurt içi ve yurt dışı araştırma bulgularına aşağıda yer verilmiştir.

Luthans, Avolio, Walumbwa ve Li (2005) tarafından Çin'de yapılan araştırma, özel ve devlete ait olmak üzere üç fabrikada gerçekleştirilmiş ve Çinli işçilerin pozitif psikolojik sermaye ile performansları arasındaki ilişki incelenmiştir. Sonuçlar; işçilerin umut, iyimserlik ve esneklik durumları ayrı ayrı ele alındığında ve üç kavram psikolojik sermayenin temel bileşeni haline getirildiğinde, performansları ile önemli derecede ilişkili olduğunu göstermiştir. Gooty, Gavin, Johnson, Frazier ve Snow (2009) çalışmalarında, psikolojik sermaye ile görev performansı arasında pozitif yönlü ve anlamlı bir ilişki tespit etmişlerdir. Dönmez (2014) tarafından seyahat acentası çalışanları üzerinde yapılan araştırmada, pozitif psikolojik sermaye düzeyleri ile iş performansı ve yaşam doyumu düzeyleri arasında pozitif yönlü ve anlamlı bir ilişki olduğu ortaya konulmuştur. Ancak iyimserlik ve psikolojik dayanıklılık alt boyutlarının iş performansında, psikolojik dayanıklılık boyutunun ise yaşam doyumunda etkisinin bulunmadığı sonucuna varılmıştır. Saithong-in (2016) tarafından yapılan çalışmada; psikolojik sermayenin işin coşkusu, işe bağlılık ve iş yeterliliği gibi aracı etkilerinin iş performansı üzerine olan etkisi incelenmiştir. Veriler, Tayland'daki yeminli mali müşavirlerden anket yoluyla toplanmış olup, sonuçlara göre psikolojik sermayenin iş performansı üzerinde olumlu etkisi olduğu ortaya konulmuştur. Muthukumar, Riasudeen ve Mathivanan (2017) tarafından Hindistan'da Ar-Ge 
sektöründe çalışan bilim insanları üzerinde yürütülen araştırmada, psikolojik sermaye ile iş performansı arasındaki ilişki incelenmiştir. Veriler, anket yoluyla Hindistan genelindeki sekiz devlet araştırma ve geliştirme laboratuvarında 525 bilim adamından oluşan bir örneklemden toplanmış ve yapısal eşitlik modellemesi ile analiz edilmiştir. Sonuçlara göre, psikolojik sermaye ile iş performansı arasında pozitif ve anlamlı bir ilişki olduğu kanaatine varılmıştır. Yapılan literatür araştırmasına göre psikolojik sermaye ile performans arasındaki ilişkinin anlamlı olduğu görülmektedir. Bu bilgiler ışığında aşağıdaki hipotez kurulmuştur.

$\mathrm{H}_{1}$ : Psikolojik sermaye, bireysel performansı pozitif yönde etkilemektedir.

Psikolojik sermaye ile birey-örgüt uyumu ilişkisini doğrudan inceleyen bir araştırmaya yerli ve yabancı literatürde rastlanılmamış olup, bu doğrultuda aşağıdaki hipotez öngörülmüştür.

$\mathrm{H}_{2}$ : Psikolojik sermaye, birey-örgüt uyumunu pozitif yönde etkilemektedir.

Birey-örgüt uyumu ile performans arasındaki ilişkinin incelendiği yurt içi ve yurt dışı araştırma bulgularına aşağıda yer verilmiştir.

Vilela, González ve Ferrín (2008)'in İspanya'da gerçekleştirdiği araştırma sonucunda, çalışanların bireyörgüt uyumu ile satış performansları arasında anlamlı bir ilişki olmadığı fakat birey-örgüt uyumunun kişilerdeki iş tatminini yükselttiği bulgusuna ulaşılmıştır. Kurtpınar (2011), birey-örgüt uyumunun bireysel performans üzerindeki etkisinde kişilik özellikleri ve işe adanmışlığın rolünü incelemiş olup, birey-örgüt uyumu yükseldikçe çalışanların performansının da yükseldiğini belirlemiştir. Farooquia ve Nagendra (2014) tarafından, birey-örgüt uyumunun çalışan memnuniyeti ve çalışanların performansı üzerine etkisinin incelendiği araştırmada; örgüte uyumu yüksek olan bireyin iş tatmininin yükseldiği, buna bağlı olarak da performansının arttığı ortaya konulmuştur. Tuna (2014) tarafından yapılan araştırmada, birey-örgüt uyumunun bireysel performans üzerindeki etkisinde, örgüt ikliminin aracılık rolü incelenmiş ve birey-örgüt uyumu ile bireysel performans arasında anlamlı bir ilişkinin olduğu tespit edilmiştir. Özdemir (2017)'in eğitim sektöründe görevli öğretmenler üzerinde yaptığı araştırmada, lider desteği ve örgütsel adalet algısının iş performansı üzerine etkisinde birey-örgüt uyumunun aracılık rolünü incelenmiş olup, bireyörgüt uyumu ile kişilerin iş performansı arasında pozitif yönde ve güçlü bir ilişki olduğu saptanmıştır. Literatürdeki birey-örgüt uyumu ile performans arasındaki ilişkinin anlamlı etkisini konu alan araştırmaların neticesinde aşağıdaki hipotez kurulmuştur.

$\mathrm{H}_{3}$ : Birey-örgüt uyumu, bireysel performansı pozitif yönde etkilemektedir.

Yerli ve yabancı literatürde, psikolojik sermaye ile performans arasındaki ilişkide birey-örgüt uyumunun aracılık rolünü doğrudan konu alan bir araştırmaya rastlanılmamış olup, bu doğrultuda aşağıdaki hipotez öngörülmüştür.

$\mathrm{H}_{4}$ : Psikolojik sermayenin bireysel performans üzerindeki etkisinde, birey-örgüt uyumu aracılık rolü üstlenmektedir.

\section{Araştırmanın Yöntemi}

Araştırma sonucunda elde edilen verilerin değerlendirilmesi SPSS (Statistical Package for the Social Sciences) 18.0 programı ile yapılmış olup, basıklık ile çarpıklık değerleri dikkate alınarak parametrik testler kullanılmıştır (Tabachnick ve Fidell, 2013). Psikolojik sermaye, bireysel performans ve birey-örgüt uyumu değişkenlerine ilişkin veriler analize tabi tutularak ortalama ( $\mathrm{x}$ ), standart sapma (S.S.) ve değişkenler arasındaki korelasyonlar incelenmiştir. Kategorik değişkenler yüzde (\%) ve sayı (N) ile gösterilmiştir. Ölçeklere ilişkin güvenirlik ve geçerlik analizleri SPSS 18.0 ve AMOS (Analysis of Moment Structures) 22.0 programları ile yapılmıştır. Psikolojik sermaye, bireysel performans ve birey-örgüt uyumu ölçekleri arasındaki korelasyonel ilişki Pearson ilişki testi ile analiz edilmiştir. Araştırmanın hipotezlerini test etmek amacıyla ise yapısal eşitlik modellemesinden yararlanılmıştır.

\subsection{Araştırma Modeli}

Araştırma modelinin oluşturulmasında, yerli ve yabancı literatür taraması sonucunda elde edilen teorik bilgiler ile daha önce yapılan araştırmaların bulguları etkili olmuştur. Araştırmada kullanılacak olan değişkenler, araştırmanın modelini ortaya koymadan önce belirlenmiştir. Modelde toplam üç değişken 
bulunmaktadır. Psikolojik sermaye modelin bağımsız değişkenini oluştururken, bireysel performans bağımlı değişkeni, birey-örgüt uyumu ise aracı değişkeni oluşturmaktadır. Bu bağlamda, araştırmanın modeli aşağıda yer almaktadır.

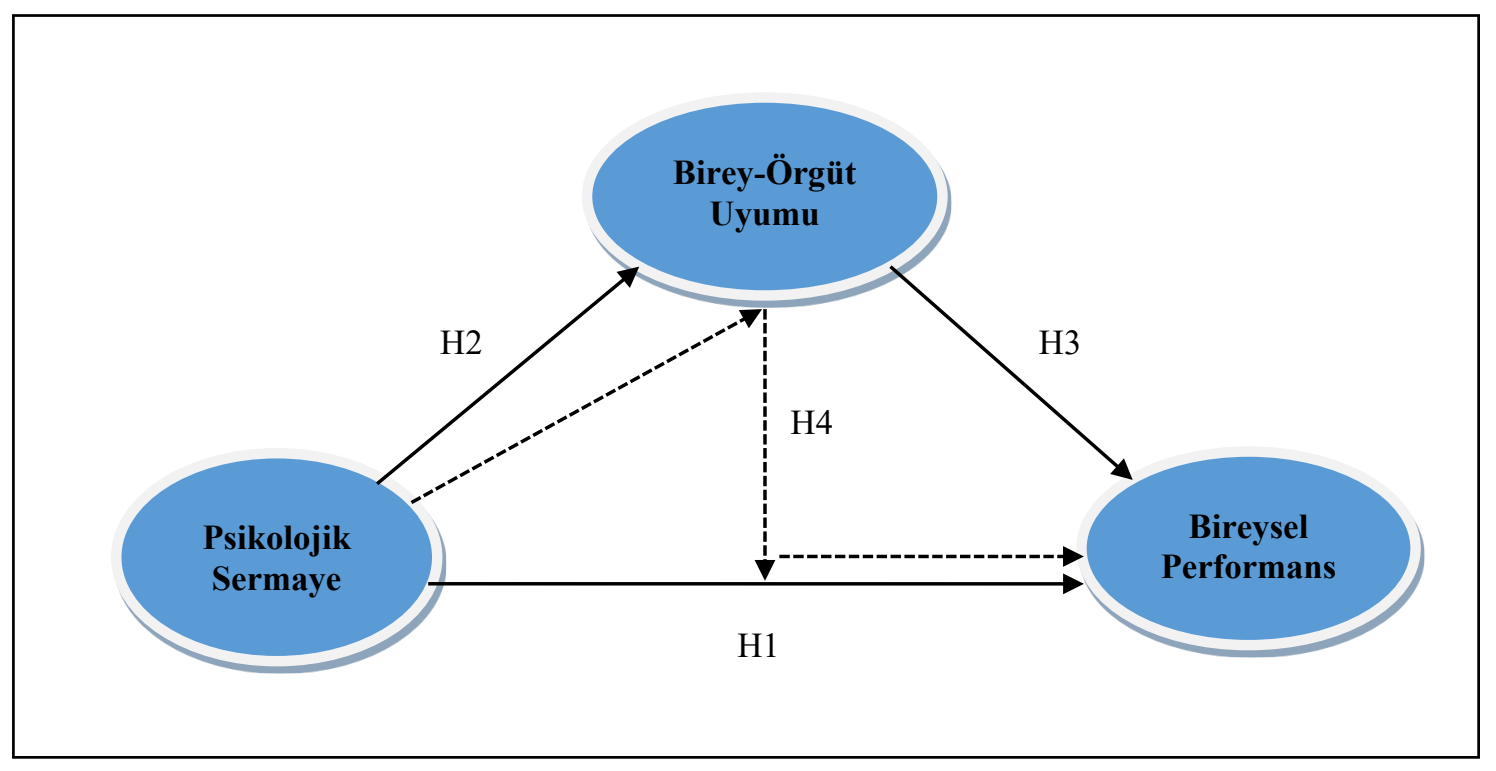

Şekil 1. Araştırmanın Modeli

\section{2. Örneklem}

Araştırmanın evrenini; Türkiye'de bulunan bütün vakıf üniversitelerinde 2016-2017 eğitim-öğretim yılı bahar döneminde görev yapan akademik personel oluşturmaktadır. Yükseköğretim Kurulu Başkanlığı'nın (YÖK) internet sitesinden 19.03.2017 tarihinde alınan bilgilere göre, söz konusu dönemde akademik kadrolarda bulunan kişi sayısı 20.841'dir (YÖK, 2017).

Araştırma kapsamında, araştırma evrenindeki tüm kişilere ulaşılmasının mümkün olmaması sebebiyle örnekleme yoluna gidilmiştir. Araştırmanın veri toplama aşamasında, olasılıklı örnekleme yöntemlerinden basit tesadüfi örnekleme tekniği kullanılmıştır. Araştırma verilerinin toplanması amacıyla oluşturulan anket formu, mail yoluyla ve online anket sistemi aracılığı ile katılımcılara ulaştıılarak, kendilerinden anketi cevaplamaları istenilmiştir. Anketlere 503 katılımcı geri dönüş yapmış olup, anketi eksiksiz dolduran 433 katılımcının cevapları değerlendirmeye alınmıştır.

Ankete cevap veren katılımcılardan yaşı 20-35 arası olanların oranı \%46,9 (N=203), 36- 50 arası olanların oranı \%33,3 ( $\mathrm{N}=144), 51$ ve üzeri olanların oranı \%19,9 $(\mathrm{N}=86)$; erkeklerin oranı \%44,6 ( $\mathrm{N}=193)$ iken kadınların oranı \%55,4 (N=240); evlilerin oranı \%62,1 ( $\mathrm{N}=269)$ iken bekar olanların oranı \%37,9 $(\mathrm{N}=164)^{\prime}$ dur.

Katılımcılardan yüksek lisans mezunu olanların oranı \%24,2 ( $\mathrm{N}=105)$, doktora mezunu olanların oranı \%58,2 $(\mathrm{N}=252)$, post doktora mezunu olanların oranı \%17,6 (N=76); akademik unvanı okutman olanların oranı \%1,6 $(\mathrm{N}=7)$, araştırma görevlisi olanların oranı \%29,8 $(\mathrm{N}=129)$, araştırma görevlisi doktor olanların oranı \%3,7

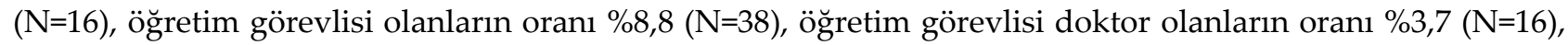
yardımcı doçent olanların oranı \%33,0 ( $\mathrm{N}=143)$, doçent olanların oranı $\% 7,2(\mathrm{~N}=31)$, profesör olanların oranı ise $\% 12,2(\mathrm{~N}=53)^{\prime}$ dir.

Katılımcılardan akademik çalışma alanı fen bilimleri olanların oranı \%20,6 (N=89), sağlık bilimleri olanların oranı \%13,2 ( $\mathrm{N}=57)$, sosyal bilimler olanların oranı \%66,3 ( $\mathrm{N}=287)$; akademik deneyimi 1-5 yıl arası olanların oranı \%38,6 ( $=167), 6-10$ y1l arası olanların oranı \%27,7 $(\mathrm{N}=120), 11-15$ y1l arası olanların oranı \%10,4 $(\mathrm{N}=45), 16$ yıl ve üzeri olanların oranı $\% 23,3(\mathrm{~N}=101)^{\prime}$ tür.

\subsection{Veri Toplama Araçları}

Araştırmada kullanılan anket formu dört bölümden oluşmaktadır. Anket formunun birinci bölümünü, katılımcıların demografik özellikleri ile ilgili sorular oluşturmaktadır. Psikolojik Sermaye Ölçeği ikinci bölümde, Bireysel Performans Ölçeği üçüncü bölümde ve Birey-Örgüt Uyumu Ölçeği ise dördüncü bölümde kullanılmıştır. 
Psikolojik Sermaye Ölçeği:

Araştırmada, Luthans ve arkadaşları tarafından (2007) geliştirilen ve literatürde en çok kullanılan dört boyutlu (öz yeterlilik, umut, iyimserlik ve dayanıklılık) psikolojik sermaye ölçeği kullanılmıştır. Toplamda 24 maddelik yargı cümlelerinden oluşan ölçeğin Çetin ve Basım (2012) tarafından Türkçe'ye uyarlanması yapılmıştır. Katılımcların yargı cümlelerine katılıp katılmadıklarını tespit etmek için 6'lı likert tipi ölçekten yararlanılmıştır. Ölçekte olumsuz yargı belirten ifadeler ise ters kodlanmıştır.

Bireysel Performans Ölçeği:

Araştırmada; başlangıçta Kirkman ve Rosen (1999) daha sonra ise Sigler ve Pearson (2000) tarafından geliştirilip, Çöl (2008) tarafından Türkçe'ye uyarlanan 4 maddeli ve tek boyutlu ölçek kullanılmıştır. Katılımcıların yargı cümlelerine katılıp katılmadıklarını tespit etmek için 5'li likert tipi ölçekten yararlanılmıştır.

\section{Birey-Örgüt Uyumu Ölçĕği:}

Araştırmada, birey-örgüt uyumu düzeyini belirlemek için Netemeyer vd., (1997) tarafından geliştirilen 4 maddeli ölçek kullanılmıştır. Ölçek Elçi vd., (2008) tarafından Türkçe'ye uyarlanmış ve tek boyutludur. Katılımcıların yargı cümlelerine katılıp katılmadıklarını tespit etmek için 5'li likert tipi ölçekten yararlanılmıştır.

Psikolojik sermaye, bireysel performans ve birey-örgüt uyumu ölçeklerinin yapı geçerliğini istatistiksel açıdan tespit etmek için açımlayıcı faktör analizi (AFA) tekniği kullanılmıştır. Araştırmada AFA, SPSS 18.0 istatistik programı kullanılarak yapılmıştır. Faktör modelinin uygunluğunu ve ana kütle içindeki değişkenler arasında bir ilişki olup olmadığını test etmek amacıyla ise Bartlett küresellik testi uygulanmıştır. Faktör analizinin geçerliğini ve örneklemin büyüklüğünü test etmek için de Kaiser-Meyer-Olkin (KMO) testi kullanılmıştır (Erkmen ve Esen, 2012: 62). KMO testi ölçüm sonucunun 0.50 ve daha yüksek, Bartlett küresellik testi sonucunun da istatistiksel olarak anlamlı olması gerekmektedir. Ölçeklerin güvenirlik düzeylerinin belirlenmesi için ise Cronbach's Alpha katsayısı hesaplanmıştır.

Psikolojik Sermaye Faktör Analizleri:

Tablo 1. KMO ve Bartlett Testi Sonuçları

\begin{tabular}{llr}
\hline KMO & &, 951 \\
\hline \multirow{3}{*}{ Bartlett Testi } & Ki-Kare & 6000,849 \\
\cline { 2 - 3 } & Sd & 231 \\
\cline { 2 - 3 } & $\mathrm{P}$ & 0,000 \\
\hline
\end{tabular}

Analiz sonucuna göre KMO değeri 0,50 'den büyük ve Bartlett testi $\left(\chi^{2}(231)=6000,849 ; p<.001\right)$ anlaml bulunmuştur. Buna göre ölçek, faktör analizine uygundur (Altunışık vd., 2007: 225-226). Yapılan açımlayıcı faktör analizi sonucuna göre, faktör yükü değerinin düşüklüğü $\left(0,4^{\prime}\right.$ ün altında bulunması) sebebiyle iki madde ölçekten çıkarılmış (1. ve 19.) olup, ölçeğin yirmi iki maddeden ve tek boyuttan oluştuğu belirlenmiştir. Ölçeğin toplam varyansı açklama oranı \%49,117'dir. Sosyal bilimlerde bu düzeyin \%40 ile \%60 arasında olmasının yeterli olduğu kabul edilmektedir (Karagöz, 2016: 880). Analiz sonucunda elde edilen güvenirlik katsayısı ise 0,947 'dir. Buna göre ölçeğin güvenirlik düzeyi çok yüksektir (Tavşancıl, 2014: 29). Orijinal ölçekte dört faktörle temsil edilen psikolojik sermaye kavramı, boyutların birbiri ile yüksek ilişki göstermesi sebebi ile ayrışmadığından bu araştırmada tek faktörle ifade edilmiştir.

Bireysel Performans Faktör Analizleri:

Tablo 2. KMO ve Bartlett Testi Sonuçları

\begin{tabular}{llr}
\hline KMO & &, 809 \\
\hline \multirow{3}{*}{ Bartlett Testi } & Ki-Kare & 587,219 \\
\cline { 2 - 3 } & Sd & 6 \\
\cline { 2 - 3 } & $\mathrm{P}$ & 0,000 \\
\hline
\end{tabular}

Analiz sonucuna göre, KMO değeri 0,50'den büyük ve Bartlett testi $(\chi 2(6)=587,219$; $p<.001)$ anlamlı bulunmuştur. Yapılan faktör analizi sonucuna göre, bireysel performans ölçeğinin dört maddeden ve tek 
O. S. Özkan - T. Omay 11/2 (2019) 743-757

boyuttan oluştuğu belirlenmiştir. Ölçeğin toplam varyansı açıklama oranı \%65,369 ve güvenirlik katsayısı 0,823 olup, ölçeğin güvenirlik düzeyi çok yüksektir.

Birey-Örgüt Uyumu Faktör Analizleri:

Tablo 3. KMO ve Bartlett Testi Sonuçları

\begin{tabular}{lrr}
\hline KMO & &, 829 \\
\hline \multirow{3}{*}{ Bartlett Testi } & Ki-Kare & 1335,739 \\
\cline { 2 - 3 } & Sd & 6,000 \\
\cline { 2 - 3 } & P & 0
\end{tabular}

Analiz sonucuna göre, KMO değeri 0,50 'den büyük ve Bartlett testi $\left(\chi^{2}{ }_{(6)}=1335,739 ; p<.001\right)$ anlamlı bulunmuştur. Yapılan faktör analizi sonucuna göre, bireysel performans ölçeğinin dört maddeden ve tek boyuttan oluştuğu belirlenmiştir. Ölçeğin toplam varyansı açıklama oranı $\% 81,127$ ve güvenirlik katsayısı 0,922 olup, ölçeğin güvenirlik düzeyi çok yüksektir.

Ölçeklerin yapı geçerliğinin keşfedilmesinin ardından, geçerliğinin test edilmesi amacı ile doğrulayıcı faktör analizi (DFA) yapılmıştır. Araştırmada DFA, AMOS 22.0 programı ile yapılmış olup; psikolojik sermaye, bireysel performans ve birey-örgüt uyumu ölçeklerinin açımlayıcı faktör analizi sonucuna göre tek boyutlu faktör yapıları incelenmiştir.

Katılımcıların psikolojik sermayelerini tespit etmeye yönelik olarak kullanılan ölçeğe, birincil seviyede tek faktörlü model analizi uygulanmıştır. Analiz sonuçları değerlendirildiğinde bazı uyum indekslerinin kabul edilebilir sinırlar içerisinde olmadığ 1 görülmüştür (CMIN/DF=4.22; GFI=.84; CFI=.89; RMSEA=.08). Faktör yapısındaki uyumu yükseltebilmek adına düzeltme indekslerine tekrar bakılmış ve tek boyutlu ölçeğin hata terimleri arasında iyileştirme yapılmasına karar verilmiştir. İyileştirmelerin kuramsal olarak desteklenebilir olması adına benzer boyutları ölçümlemeyi amaçlayan aynı alt boyutların hata terimleri ilişkilendirilmiştir (Meydan ve Şeşen, 2015: 82). Bu sebeple tek boyutlu ölçekte çeşitli hata terimleri arasında iyileştirmeler yapılmış ve bu sayede uyum iyiliği değerlerinin yükseldiği görülmüştür. Gerekli düzeltmelerin yapılmasının ardından tek faktörlü modele ait değerler kabul edilebilir sınırlara ulaşmıştır (CMIN/DF=2.79; GFI=.90; CFI=.94; RMSEA=.06).

Katılımcıların bireysel performanslarını ölçmek amacıyla kullanılan ölçeğin geçerliğini test etmek için yapılan doğrulayıcı faktör analizi sonucunda, ölçeğin tüm uyum indekslerini sağladığı belirlenmiştir (CMIN/DF=0.56; GFI=.99; CFI=1.0; RMSEA=.00).

Katılımcıların birey-örgüt uyumlarını belirlemek amacıyla kullanılan ölçeğin geçerliğini test etmek için yapılan doğrulayıcı faktör analizi sonucunda, ölçeğin tüm uyum indekslerini sağladığı gözlenmiştir (CMIN/DF=1.29; GFI=.99; CFI=1.0; RMSEA=.02).

Tablo 4. Ölçeklerin Uyumuna İlişkin İstatistiksel Değerler

\begin{tabular}{lccc}
\hline Uyum İndeksleri & $\begin{array}{c}\text { Psikolojik } \\
\text { Sermaye Ölçeği }\end{array}$ & $\begin{array}{c}\text { Bireysel } \\
\text { Performans Ölçeği }\end{array}$ & $\begin{array}{c}\text { Birey-Örgüt } \\
\text { Uyumu Ölçeği }\end{array}$ \\
\hline CMIN/DF & 2.79 & 0.56 & 1.29 \\
GFI & .90 & .99 & .99 \\
CFI & .94 & 1.0 & 1.0 \\
RMSEA & .06 & .00 & .02 \\
\hline
\end{tabular}

CMIN/DF=Relative Chi-square; GFI=Goodness Of Fit Index; CFI=Comparative Fit Index; RMSEA=Root Mean Square Error of Approximation 


\section{Bulgular}

Araştırmada elde edilen verilere; öncelikle psikolojik sermaye, bireysel performans ve birey-örgüt uyumu değişkenlerinin ortalama ve standart sapmaları ile bu değişkenler arasındaki korelasyon katsayılarının belirlenmesine yönelik analizler yapılmıştır. Bu analiz sonucunda elde edilen ortalama, standart sapma ve korelasyon değerleri Tablo 5 'te görülmektedir.

Tablo 5. Değişkenler Arasındaki İlişkilere Yönelik Bulgular

\begin{tabular}{|c|c|c|c|c|c|}
\hline Değişkenler & $\bar{x}$ & S.S. & $\begin{array}{c}\text { Psikolojik } \\
\text { Sermaye } \\
\text { Ölçeği }\end{array}$ & $\begin{array}{l}\text { Bireysel } \\
\text { Performans } \\
\text { Ölçeği }\end{array}$ & $\begin{array}{l}\text { Birey-Örgüt } \\
\text { Uyumu Ölçeği }\end{array}$ \\
\hline Psikolojik & & & & & \\
\hline $\begin{array}{l}\text { Sermaye } \\
\text { Ölçeği }\end{array}$ & 4.37 & .76 & 1 & $.738^{* *}$ & $.514^{* *}$ \\
\hline $\begin{array}{l}\text { Bireysel } \\
\text { Performans } \\
\text { Ölçeği }\end{array}$ & 3.81 & .69 & $.738^{* *}$ & 1 & $.428^{* *}$ \\
\hline $\begin{array}{l}\text { Birey-Örgüt } \\
\text { Uyumu } \\
\text { Ölçeği }\end{array}$ & 3.13 & .94 & $.514^{* *}$ & $.428^{* *}$ & 1 \\
\hline
\end{tabular}

${ }^{* *} \mathrm{p}<.01$

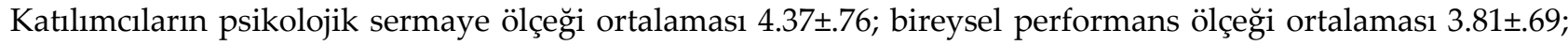

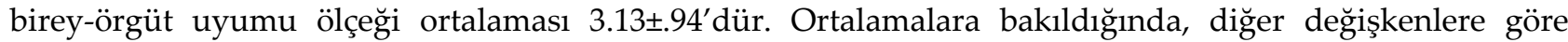
psikolojik sermaye değişkeninin ortalamasının daha yüksek olduğu görülmektedir.

Araştırmanın temelini oluşturan modeli test ederek psikolojik sermaye, bireysel performans ve birey-örgüt uyumu arasındaki ilişkiyi ortaya çıkarmak için yapılan korelasyon analizi bulguları, değişkenler arasında anlamlı ilişki olduğunu göstermektedir. Psikolojik sermaye ile bireysel performans arasında yüksek düzeyde pozitif yönlü bir ilişki (r=.738 p<.01), psikolojik sermaye ile birey-örgüt uyumu arasında orta düzeyde pozitif yönlü bir ilişki $(\mathrm{r}=.514 \mathrm{p}<.01)$ bulunmaktadır. Bireysel performans ile birey-örgüt uyumu arasında ise zayıf düzeyde pozitif yönlü bir ilişki (r=.428 p<.01) bulunmaktadır (Kalaycı, 2006: 116).

Araştırmanın hipotezlerini test etmek amacıyla yapısal eşitlik modellemesi kullanılmış olup, aracılık etkisini belirlemek için de Baron ve Kenny'nin (1986) yöntemi referans alınmıştır.

Analiz sonuçlarına göre psikolojik sermaye, bireysel performansı pozitif yönde ve anlamlı düzeyde etkilediğinden $\mathrm{H}_{1}$ kabul edilmiştir $(\beta=.86$; $\mathrm{p}<.05)$. Psikolojik sermaye, birey-örgüt uyumunu pozitif yönde ve anlamlı düzeyde etkilediğinden $\mathrm{H}_{2}$ kabul edilmiştir $(\beta=.21 ; \mathrm{p}<.05)$. Birey-örgüt uyumu, bireysel performansı pozitif yönde ve anlamlı düzeyde etkilediğinden $\mathrm{H}_{3}$ kabul edilmiştir $(\beta=.19 ; \mathrm{p}<.05)$.

AMOS 22.0 yardımıyla çizilen ve yolları gösteren yapısal model Şekil 2' de verilmiştir. Yapısal modele ilişkin uyum iyiliği değerleri incelendiğinde, değerlerin kabul edilebilir sınırlar içerisinde bulunduğu görülmektedir (CMIN/DF=2.90; GFI=.89; $\mathrm{CFI=.91;} \mathrm{RMSEA=.06).} \mathrm{Değişkenler} \mathrm{arasındaki} \mathrm{etkiyi} \mathrm{tespit} \mathrm{etmek}$ maksadıyla yapılan yol analizinin sonuçlarına ise Tablo 6 ' da yer verilmiştir. 


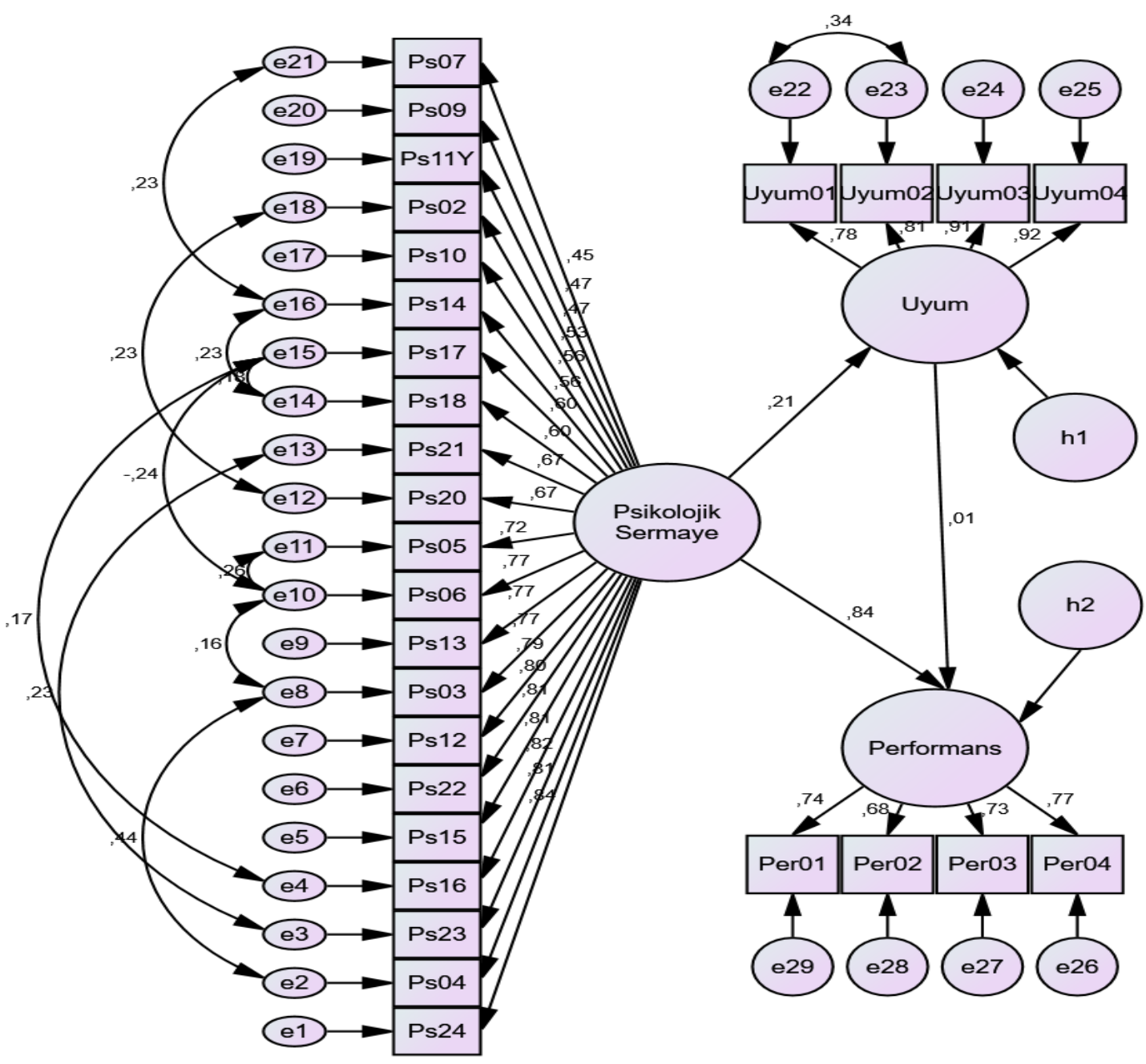

Şekil 2. Yapısal Eşitlik Modeli

Tablo 6. Yapısal Modelin Yol Analizine İlişkin Bulgular

\begin{tabular}{lccc}
\hline Yapısal Modele İlişkin Yollar & Regresyon Katsayısı & S.E. & P \\
\hline Psikolojik Sermaye $\rightarrow$ Birey-Örgüt Uyumu & .21 & .04 & $* * *$ \\
Birey-Örgüt Uyumu $\rightarrow$ Bireysel Performans & .01 & .03 & .833 \\
Psikolojik Sermaye $\rightarrow$ Bireysel Performans & .84 & .03 & $* * *$ \\
\hline
\end{tabular}

Aracılık etkisini tespit etmek amacıyla yapılan analiz sonucuna göre (Bk. Şekil 2 ve Tablo 6) psikolojik sermaye, birey-örgüt uyumunu pozitif yönde ve anlamlı düzeyde etkilemektedir $(\beta=.21 ; \mathrm{p}<.05)$. Bununla birlikte psikolojik sermaye, bireysel performansı da pozitif yönde ve anlamlı düzeyde etkilemektedir $(\beta=.84$; $\mathrm{p}<.05)$. Tahmin değerleri incelendiğinde; psikolojik sermayenin bireysel performans üzerindeki etkisinin, birey-örgüt uyumu üzerindeki etkisinden daha fazla olduğu görülmektedir.

Aracı değişken, bağımsız değişken ile birlikte modele dahil edildiğinde; bağımsız değişkenin bağımlı değişken üzerindeki etkisi azalırken (.86'dan $\left..84^{\prime} \mathrm{e}\right)$, aracı değişkenin bağımlı değişken üzerindeki etkisinin anlamlı olmadığı görülmektedir. Diğer bir ifade ile birey-örgüt uyumu, bireysel performansı istatistiksel olarak anlamlı düzeyde etkilememektedir $(\beta=.01 ; \mathrm{p}>05)$. Birey-örgüt uyumunun, bireysel performans üzerindeki etkisinin anlamlı olmaması nedeni ile aracılık rolü tespit edilemediğinden $\mathrm{H}_{4}$ reddedilmiştir.

\section{Tartışma ve Sonuç}

Araştırma; psikolojik sermaye ile bireysel performans ve birey-örgüt uyumu arasındaki ilişkiyi ortaya koymayı ve bu ilişkide birey-örgüt uyumunun aracılık rolünü tespit etmeyi amaçlamaktadır. Yerli ve yabancı literatür incelendiğinde; psikolojik sermaye ile bireysel performans arasında ve birey-örgüt uyumu ile bireysel performans arasındaki ilişkiyi ortaya koyan çalışmaların olduğu belirlenmiş, ancak psikolojik sermaye ile birey-örgüt uyumu ilişkisi bulunan veya psikolojik sermaye ile bireysel performans arasındaki 
ilişkide birey-örgüt uyumunun aracılık rolünü aynı model içerisinde birleştiren bir çalışmaya rastlanılmamıştır. Bu doğrultuda; psikolojik sermaye, bireysel performans ve birey-örgüt uyumu ilişkisini ve bu ilişkide birey-örgüt uyumunun aracılık rolünü ifade eden yapısal bir model oluşturulmuştur.

Araştırma sonuçları hipotezler açısından değerlendirildiğinde, ilk üç hipotezin desteklendiği ancak dördüncü hipotezin desteklenmediği gözlenmektedir. Birinci araştırma hipotezi, psikolojik sermayenin bireysel performansı pozitif yönde ve anlamlı düzeyde etkilediğini göstermektedir. Elde edilen bu bulgu Luthans, Avolio, Walumbwa ve Li (2005); Luthans, Norman, Avolio ve Avey (2008); Luthans, Avey, ClappSmith ve Li (2008); Luthans, Avey, Avolio ve Peterson (2010); Erkuş ve Fındıklı (2013); Uğurlu Kara (2014); Bitmiş (2014); Durrah, Alhamoud ve Khan (2016); Muthukumar, Riasudeen ve Mathivanan (2017); Alessandri, Consiglio, Luthans ve Borgogni (2018) tarafından elde edilen bulgular ile paralellik göstermektedir. Bu sonuca göre psikolojik sermayesi yüksek olan birey, pozitif çıktıların elde edilmesi yönünde eğilimli hale gelerek çalışma isteğini artıracak ve bu da süreç içerisinde daha yüksek performans sergilemesine neden olacaktır.

Araştırmanın ikinci hipotezi, psikolojik sermayenin birey-örgüt uyumunu pozitif ve anlamlı düzeyde etkilediğini ortaya koymaktadır. Psikolojik sermaye ile birey-örgüt uyumu ilişkisini doğrudan konu alan bir araştırmaya ulusal ve uluslararası literatürde rastlanılmadığından, elde edilen bu sonuç öngörülen hipotezi doğrular niteliktedir. Bu sonuca göre, psikolojik sermayesi yüksek olan bireyin çalıştı̆̆ı örgütle özdeşleşmesi ve yaptığı iş ile olan uyumunun artması neticesinde örgütün genel başarı düzeyi ve verimliliği de yükselecektir.

Bireyin içinde bulunduğu örgüt ile uyum içinde olmasını ifade eden birey-örgüt uyumu ve bireysel performans ilişkisinin incelendiği üçüncü araştırma hipotezi, birey-örgüt uyumunun bireysel performansı pozitif yönde ve anlamlı düzeyde etkilediğini göstermektedir. Elde edilen bu bulgu Karakurum (2005); Bright (2007); Kurtpınar (2011); Öcel (2013); Demir, Demir ve Nield (2015); Mostafa (2016); Özdemir (2017); Andersson, Huysentruyt, Miettinen ve Stephan (2017) tarafından elde edilen bulgular ile ayn doğrultudadır. Bu sonuca göre, örgütün amaçları ve değerleri ile özdeşleşen bireyin performansının artması neticesinde kişisel ve örgütsel hedeflere ulaşma düzeyi de yükselecektir.

Araştırmada değişkenler ikili olarak incelendiğinde; psikolojik sermaye, bireysel performans ve birey-örgüt uyumu arasında karşılıklı ilişkilerin anlamlı olduğu gözlenmektedir. Ancak aracılık etkisini belirlemek üzere yapılan analizler sonucunda; psikolojik sermayenin bireysel performans üzerindeki etkisinde, birey-örgüt uyumu aracilık rolü üstlenmediğinden araştırmanın son (dördüncü) hipotezi desteklenmemiştir. Bu sonuç, "psikolojik sermaye, birey-örgüt uyumu aracılığıyla mı bireysel performansı etkilemektedir" şeklinde belirlenmiş olan araştırmanın temel sorusunun doğrulanmadığını ortaya koymaktadır.

Araştırmada; psikolojik sermaye ölçeğinin önceden belirlenmiş veya kurgulanmış yapısının geçerliğini doğrulamak için yapılan DFA çözümlemesinde, pozitif tanımlı olması gereken kovaryans matrisinin negatif tanımlı olduğu bulgulanmıştır. Bu sonuç, ölçeğin geçerliğinin sağlanamadığı veya model ile verinin yeterli düzeyde uyum göstermediği şeklinde yorumlanabilir. Literatürde yirmi dört madde ve dört faktörle temsil edilen ölçeğin geçerliği sağlanamadığı için yapı geçerliğini tespit etmek için yapılan AFA sonucunda, ölçeğin yirmi iki maddeden ve tek faktörden oluştuğu saptanmıştır. Bunun olası nedenlerinin; ölçeğin uyarlama bir ölçek olmasından, ölçeğe ait soruların kültürümüzde farklı bir şekilde yorumlanmasından ve iyimserlik, öz yeterlilik, dayanıklılık ile umut alt boyutlarına ait olan maddelerin birbirine benzerlik göstermesinden kaynaklandığı değerlendirilmektedir. Bitmiş ve Ergeneli (2013); Çelik, Turunç ve Bilgin (2014); Yıldız (2015) tarafından yapılan araştırmalarda da ölçeğin tek faktörlü hali kullanılmıştır.

Sonuç olarak bu araştırma; psikolojik sermayenin örgütsel sonuç değişkenlerinden biri olan bireysel performans üzerindeki etkisi ile bu etkide birey-örgüt uyumunun aracılık rolünü ele alarak, örgütsel davranış alanına ve araştırmacılara katkı yapması amacıyla gerçekleştirilmiştir.

Literatüre katkıda bulunması ve hem kuramsal hem de pratik uygulamalara sahip olmasının yanı sıra araştırmanın bazı temel kısıtları da bulunmaktadır. Öncelikle, araştırma doğası gereği kesitseldir; bu da hipotezlerin sınanması için gereken veriler tek bir dönemde toplandığından, değişkenler arası ilişkilerin anlaşılmasını sınırladığı anlamına gelmektedir. Diğer bir kısıt ise, bireysel performans için katılımcıların kendi performanslarını değerlendirmelerinin sosyal istenirlik riskini ortaya çıkarmasıdır. 
Gelecekteki araştırmalarda; psikolojik sermayenin bireysel performans üzerindeki etkisinde, birey-örgüt uyumunun aracılık veya düzenleyici rolünü içeren farklı örneklem grupları ile çalışmalar yapılmalıdır. Bununla birlikte, gelecekte psikolojik sermaye ve birey-örgüt uyumu ile ilgili araştırmaların yapılması literatürün geliştirilmesine katkı sağlayacaktır. Psikolojik sermaye ile birey-örgüt uyumu ilişkisini ve psikolojik sermaye ile bireysel performans arasındaki ilişkide birey-örgüt uyumunun aracılık veya düzenleyici rolünü ele alan çalışmaların hem devlet hem de vakıf üniversitelerinde yapılması, sonuçların genelleştirilmesine ve karşılaştırmaların yapılmasına imkan sağlayacaktır. Araştırma değişkenleri eş zamanlı ölçüldü̈̆ü için nedensel sonuç çıkarımları yapılamamaktadır. Bu konuda yapılacak olan boylamsal çalışmalar gelecekteki araştırmalar için önem taşımaktadır. Ayrıca iyimserlik, öz yeterlilik, dayanıklılık ve umut alt boyutlarına yönelik Türk kültürüne özgü bir psikolojik sermaye tanımının yapılması ve kavram ile boyutların ölçümüne ilişkin bir ölçek geliştirilmesi gelecekteki ulusal araştırmalar için önemli olacaktır.

\section{Kaynakça}

Andersson, O., Huysentruyt, M., Miettinen, T., Stephan, U. (2017). Person-organization fit and incentives: a causal test, Management Science, 63 (1), 73-96.

Alessandri, G., Consiglio, C., Luthans, F., Borgogni, L. (2018). Testing a dynamic model of the 1mpact of psychological capital on work engagement and job performance, Career Development International, 23 (1), 33-47.

Akal, Z. (1996). İşletmelerde Performans Ölçüm ve Denetimi, Ankara, Milli Prodüktivite Merkezi Yayınları.

Altunışık, R., Coşkun, R., Bayraktaroğlu, S., Yıldırım, E. (2007). Sosyal Bilimlerde Araştırma Yöntemleri (5. Baskı), Sakarya, SakaryaYayıncilık.

Baron, R. M., Kenny, D. A. (1986). The moderator-mediator variable distinction in social psychology research: conceptual, strategic and statistical considerations, Journal of Personallity and Social Psychology, 51 (6), 1173-1182.

Barutçugil, İ. (2002). Performans Yönetimi, İstanbul, Kariyer Yayınları.

Bitmis, M. G., Ergeneli, A. (2013). The role of psychological capital and trust in individual performance and job satisfaction relationship: a test of multiple mediation model, Procedia-Social and Behavioral Sciences, 99, 173-179.

Bitmiş, M. G. (2014). Öncülleri ve Sonuçları ile Psikolojik Sermaye: Sağlık Çalışanları Üzerine Bir Araştırma, Yayımlanmamış Doktora Tezi, Hacettepe Üniversitesi Sosyal Bilimler Enstitüsü.

Bretz, R. D., Ash, R. A., Dreher, G. F. (1989). Do people make the place? an examination of the attractionselection-attrition hypothesis, Personnel Psychology, 42, 561-581.

Bright, L. (2007). Does person-organization fit mediate the relationship between public service motivation and the job performance of public employees?, Review of Public Personnel Administration, 27 (4), 361379 .

Chatman, J. A. (1989). Improving interactional organizational research: a model of person-organization fit, Academy of Management Review, 14 (3), 333-349.

Cable, D. M., Judge, T. A. (1994). Pay preferences and job search decisions: a person-organization fit perspective, Personnel Psychology, 47 (2), 317-348.

Caprara, G. V., Cervone, D. (2003). A Conception of Personality for a Psychology of Human Strengths: Personality as an Agentic, Self Regulating System. In L. G. Aspinwall, U. M. Staudinger, (Ed.), A Psychology of Human Strenghts: Fundamental Questions and Future Directions for a Positive Psychology (6174). Washington: DC American Psychological Association.

Cheng, Z. (2014). Research on recruitment model based on person-organization fit, International Journal of Business Administration, 5 (2), 126-131.

Çetin, F., Basım, H. N. (2012). Örgütsel psikolojik sermaye: bir ölçek uyarlama çalışması, Amme İdaresi Dergisi, 45 (1), 121-137. 
Çetin, F., Şeşen, H., Basım, H. N. (2013). Örgütsel psikolojik sermayenin tükenmişlik sürecine etkileri: kamu sektöründe bir araştırma, Anadolu Üniversitesi Sosyal Bilimler Dergisi, 13 (3), 95-107.

Çelik, M., Turunç, Ö., Bilgin, N. (2014). Çalışanların örgütsel adalet algılarının psikolojik sermaye üzerine etkisi: çalışanların iyilik halinin düzenleyici rolü, Dokuz Eylül Üniversitesi Sosyal Bilimler Enstitüsü Dergisi, 16 (4), 559-585.

Çöl, G. (2008). Algılanan güçlendirmenin işgören performası üzerine etkileri, Doğuş Üniversitesi Dergisi, 9 (1), $35-46$.

Demir, M., Demir, S. S., Nield, K. (2015). The relationship between person-organization fit, organizational 1dentification and work outcomes, Journal of Business Economics and Management, 16 (2), 369-386.

Durrah, O., Alhamoud, A., Khan, K. (2016). Positive psychological capital and job performance: the mediating role of job satisfaction, Ponte Academic Journal, 72 (7), 214-225.

Dönmez, B. (2014). Pozitif Psikolojik Sermaye İle İşe İlişkin Duyuşsal İyilik Algısı, İş Doyumu, İşgören Performansı ve Yaşam Doyumu İlişkilerinin Seyahat Acentası Çalışanları Örnekleminde İncelenmesi, Yayımlanmamış Doktora Tezi, Mersin Üniversitesi Sosyal Bilimler Enstitüsü.

Elçi, M., Alpkan, L., Çekmecelioğlu, G. H. (2008). The influence of person organization fit on the employee's perception of organizational performance, 4th International Strategic Management Conference, Sarajevo, Bosnia-Herzegovnia, 19-21, 587-593.

Erkmen, T., Esen, E. (2012). Psikolojik sermaye konusunda 2003-2011 yıllarında çalışmaların kategorik olarak incelenmesi,Mustafa Kemal Üniversitesi Sosyal Bilimler Enstitüsü Dergisi, 9 (19), 89-103.

Erkuş, A., Fındıklı, M. A. (2013). Psikolojik sermayenin iş tatmini, iş performansı ve işten ayrılma niyeti üzerindeki etkisine yönelik bir araştırma, İstanbul Üniversitesi Isşletme Fakültesi Dergisi, 42 (2), 302-318.

Erkmen, T., Esen, E. (2013). Psikolojik sermaye ölçeğinin geçerlilik ve güvenilirlik çalışması, Öneri Dergisi, 10 (39), 23-30.

Farooqui, S., Nagendra, A. (2014). The impact of person organization fit on job satisfaction and performance of the employees, Procedia Economics and Finance, 11, 122-129.

Gooty, J., Gavin, M., Johnson, P. D., Frazier, M. L., Snow, D. B. (2009). In the eyes of the beholder: transformational leadership, positive psychological capital, and performance, Journal of Leadership and Organizational Studies, 15 (4), 353-367.

Katerberg, R. (1983). An examination of level and direction of effort and job performance, Academy of Management Journal, 26 (2), 249-257.

Karakurum, M. (2005). The Effects of Person-Organization Fit on Employee Job Satisfaction, Performance and Organizational Commitment in a Turkish Public Organization, Yayımlanmamış Yüksek Lisans Tezi, Ortadoğu Teknik Üniversitesi Sosyal Bilimler Enstitüsü.

Kalaycı, Ş. (2006). SPSS Uygulamalı Çok Değişkenli İstatistik Teknikleri (2.Baskı), Ankara, Asil Yayınları.

Karagöz, Y. (2016). SPSS ve AMOS 23 Uygulamalı İstatistiksel Analizler (1. Baskı), Ankara, Nobel Yayınları.

Keleş, H. N. (2011). Pozitif psikolojik sermaye: tanımı, bileşenleri ve örgüt yönetimine etkileri, Organizasyon ve Yönetim Bilimleri Dergisi, 3 (2), 343-350.

Kılıç, K. C. (2010). Bireysel ve örgütsel değerler arasındaki uyumun çalışanların iş davranışlarına etkileri üzerine ampirik bir çalışma, Çukurova Üniversitesi Sosyal Bilimler Enstitüsü Dergisi, 19 (1), 20-35.

Kurtpınar, M. (2011). Birey-Örgüt Uyumunun Bireysel Performans Üzerindeki Etkisinde Kişilik Özellikleri ve İșe Adanmışlığın Rolü, Yayımlanmamış Yüksek Lisans Tezi, Harp Akademileri Komutanlığ Stratejik Araştırmalar Enstitüsü.

Kümbül Güler, B. (2015). Pozitif Psikolojik Sermaye: Tanımı, Bileşenleri ve Yönetimi, A. Keser, G. Yılmaz, S. Yürür, (Ed.), Çalışma Yaşamında Davranış: Güncel Yaklaşımlar (3. Baskı) içinde (137-166). Kocaeli, Umuttepe Yayınları. 
O. S. Özkan - T. Omay 11/2 (2019) 743-757

Kristof, A. L. (1996). Person-organization fit: an integrative review of its conceptualization, measurement and implications, Personnel Psychology, 49, 1-49.

Larousse, M. (1969). Performans, İstanbul, Meydan Yayınevi.

Luthans, F. (2002). The need for and meaning of positive organizational behavior, Journal of Organizational Behavior, 23, 695-706.

Luthans, F., Youssef, C. M. (2004). Human, social, and now positive psychological capital management, Organizational Dynamics, 33 (2), 143-160.

Luthans, F., Avolio, B. J., Walumbwa, F. O., Li, W. (2005). The psychological capital of chinese workers: exploring the relationship with performance, Management and Organization Review, 1 (2), 249-271.

Luthans, F., Youssef, C. M., Avolio, B. J. (2007). Psychological Capital: Developing the Human Competitive Edge, New York, Oxford University Press.

Luthans, F., Norman, S. M., Avolio, B. J., Avey, J. B. (2008). The mediating role of psychological capital in the supportive organisational climate - employee performance relationship, Journal of Organisational Behavior, 29, 219-238.

Luthans, F., Avey, J. B., Clapp-Smith, R., Li, W. (2008). More evidence on the value of chinese workers' psychological capital: a potentially unlimited competitive resource?, The International Journal of Human Resource Management, 19 (5), 818-827.

Luthans, F., Avey, J. B., Avolio, B. J., Peterson, S. J. (2010). The development and resulting performance impact of positive psychological capital, Human Resource Development Quarterly, 21 (1), 41-67.

Linley, P. A., Joseph, S., Harrington, S., Wood, A. M. (2006). Positive psychology: past, present, and (possible) future, The Journal of Positive Psychology, 1 (1), 3-16.

Marchant, T. (1999). Strategies for improving individual performance and job satisfaction at meadowvale health, Journal of Management Practice, 2 (3), 63-70.

Meglino, B. M., Ravlin, E. C., Adkins, C. L. (1989). A work values approach to corporate culture: a field test of the values congruence process and its relationship to individual outcomes, Journal of Applied Psychology, 74 (3), 424-432.

Meydan, C. H., Şeşen, H. (2015). Yapısal Eşitlik Modellemesi Amos Uygulamaları (2. Baskı), Ankara, DetayYayıncilik.

Mostafa, A. M. S. (2016). High-performance hr practices, work stress and quit intentions in the public health sector, Public Management Review, 18 (8), 1218-1237.

Muthukumar, K., Riasudeen, S., Mathivanan, S. (2017). The impact of psychological capital on job performance: a study among indian scientists, International Journal of Business Excellence, 13 (1),79-90.

O'Reilly III, C., Chatman, J. (1986). Organizational commitment and psychological attachment: the effects of compliance, identification, and internalization on prosocial behavior, Journal of Applied Psychology, 71 (3), 492-499.

O'Reilly III, C., Chatman, J., Caldwell, D. F. (1991). People and organizational culture: a profile comparison approach to assessing person-organization fit, Academy of Management Journal, 34 (3), 487-516.

Öcel, H. (2013). Örgüt kimliğinin gücü, algılanan örgütsel prestij ve kişi-örgüt uyumu ile bağlamsal performans arasındaki ilişkiler: örgütsel bağlılığın aracı rolü, Türk Psikoloji Dergisi, 28 (71), 37-56.

Özdemir, O. (2017). Lider Desteği ve Örgütsel Adalet Algısının İş Performansına Etkisinde Kişi-Örgüt Uyumunun Aracılık Rolü: Eğitim Sektöründe Bir Araştırma, Yayımlanmamış Yüksek Lisans Tezi, Türk Hava Kurumu Üniversitesi Sosyal Bilimler Enstitüsü.

Saraç, M., Meydan, B. (2013). Birey-örgüt uyumunun bireysel sonuçlarının incelenmesine yönelik boylamsal bir çalışma, 1. Örgütsel Davranış Kongresi Bildiriler Kitabı içinde (210-214). Sakarya: Sakarya Üniversitesi. 
O. S. Özkan - T. Omay 11/2 (2019) 743-757

Saithong-in, S. (2016). Psychological capital and job performance: an empirical research of certified public accountants (cpas) in Thailand, The Business and Management Review, 7 (5), 499-506.

Sonnentag, S., Frese, M. (2002). Performance Concepts and Performance Theory, In Psychological Management of Individual Performance (3-26). Germany: Technical University of Braunschweig.

Tabachnick, B. G., Fidell, L. S. (2013). Using Multivariate Statistics (6th ed.), Boston, MA Pearson.

Tavşancıl, E. (2014). Tutumların Ölçülmesi ve SPSS ile Veri Analizi (5.Baskı), Ankara, Nobel Yayınları.

Turunç, Ö., Çelik, M. (2012). İş tatmini-kişi-örgüt uyumu ve amire güven-kişi-örgüt uyumu ilişkisinde dağıtım adaletinin düzenleyici rolü, İş, Gü̧̧ Endüstri İlişkileri ve İnsan Kaynakları Dergisi, 14 (2), 57-78.

Tuna, B. (2014). The Influence of Person-Organization Fit on Contextual Performance and Its Impact on Organizational Effectiveness: The Moderating Role of Organizational Climate, Yayımlanmamış Doktora Tezi, Yeditepe Üniversitesi Sosyal Bilimler Enstitüsü.

Uğurlu Kara, A. (2014). Pozitif Psikolojik Sermaye İle Bireysel Performans İlişkisi: Tarım Kredi Kooperatifleri Merkez Birliği Örneği, Yayımlanmamış Yüksek Lisans Tezi, Gazi Ünviversitesi Sosyal Bilimler Enstitüsü.

Vancouver, J. B., Schmitt, N. W. (1991). An exploratory examination of person- organization fit: organizational goal congruence, Personnel Psychology, 44, 333-352.

Vancouver, J. B., Millsap, R. E., Peters, P. A. (1994). Multilevel analysis of organizational goal congruence, Journal of Applied Psychology, 79 (5), 666-679.

Vilela, B. B., González, J. A. V., Ferrín, P. F. (2008). person-organization fit, Ocb and performance appraisal: evidence from matched supervisor-salesperson data set in a spanish context, Industrial Marketing Management, 37 (8), 1005-1119.

Yahyagil, M. Y. (2005). Birey ve organizasyon uyumu ve çalışanların iş tutumlarına etkisi, Marmara Üniversitesi Öneri Dergisi, 6 (24), 137-149.

Yıldız, H. (2015). Pozitif Psikolojik Sermaye, Örgütsel Güven ve Örgütsel Vatandaşlık Davranışı Arasındaki İlişkinin İncelenmesi: Bir Alan Araştırması, Yayımlanmamış Doktora Tezi,Balıkesir Üniversitesi, Sosyal Bilimler Enstitüsü, Balıkesir.

Zhao, Z., Hou, J. (2009). The study on psychological capital development on intreprenurial team, International Journal of Psychological Studies, 1 (2), 35-40. 